\title{
Buffaloes (Bubalus bubalis) mycotic eye infection: reported herd cases in Thi-Qar province, Iraq
}

\author{
Infecção ocular micótica em búfalos (Bubalus bubalis): relato de casos em \\ rebanho na província de Thi-Qar, Iraque
}

\author{
Jenan Mahmood Khalaf ${ }^{1}$ (D); Abdulkarim Jafar Karim² (1); Karima Akool Al Salihi ${ }^{3}$ (1) \\ ${ }^{1}$ University of Baghdad, College of Veterinary Medicine, Department of Preventive and Internal Medicine, Baghdad, Iraq \\ ${ }^{2}$ University of Baghdad, College of Veterinary Medicine, Baghdad, Iraq \\ ${ }^{3}$ Al Muthanna University, College of Veterinary Medicine, Department of Preventive and Internal Medicine, AlMuthanna, Iraq
}

\begin{abstract}
Buffaloes are one of the important farm animals in the south of Iraq and play an essential economical role mainly acting as dairy, meat, and draft animals. This study intended to diagnose buffalo mycotic eye infections in Thi-Qar province/Iraq. Some 250 buffaloes in the herd of 3,700 animals suffered from eye infections from December 2017 to November 2018. Eye swabs were collected from each infected eye of the affected buffaloes of both sexes before treatment. The animals were in different age groups. All samples were transferred to the laboratory in transfer media, and cultured on Sabouraud dextrose (SDA) agar with and without $0.05 \mathrm{~g} / \mathrm{mL}$ and $0.4 \mathrm{~g} / \mathrm{mL}$ chloramphenicol and cycloheximide, respectively. Later, the agars were incubated at $25^{\circ} \mathrm{C}$ and $37^{\circ} \mathrm{C}$. The total percentage of eye infection was (6.75\%), constituting $(49.2 \%)$ mycotic infections. The predominant clinical manifestations that appeared on the infected buffaloes were eye inflammation represented by congestion, lacrimation, the opacity of cornea and edema, and reduced productivity of the infected animals. Different fungal isolates were identified from the samples including Aspergillus fumigates, Aspergillus flavus, Aspergillus niger, Penicillium spp., Alternaria spp., Fusarium spp., Candida spp., Cladosporium spp., Rhodotorula spp., Mucor spp. and Rhizopus spp. Calves buffaloes below one-year-old were more prone to mycotic infection than one-year-old or more. Additionally, male buffaloes were more susceptible to infection than females. In conclusion, this study isolated various types of fungus from the inflamed eyes of buffaloes. Fungal eye infection and the potential risk factors for fungal keratitis in buffaloes were also investigated. The study also approved the rapid diagnosis of fungi by direct microscopic detection and culture. The author recommends future studies including large numbers of the buffalo herd in Iraq to determine the epidemiology of this condition in the country.
\end{abstract}

Keywords: Bubaline. Fungal eye infections. Aspergillus flavus. Mucor spp.

\section{RESUMO}

Os búfalos são um dos animais de fazenda mais importantes no sul do Iraque e desempenham um papel econômico essencial, atuando principalmente na produção de leite, carne e como animal de tração. Este estudo objetivou diagnosticar infecções oculares micóticas em búfalos na província de Thi-Qar, Iraque. 250 búfalos no rebanho de um total de 3700 animais apresentaram infecção ocular durante o período compreendido entre dezembro de 2017 e novembro de 2018. Os esfregaços oculares foram colhidos dos olhos infectados dos búfalos afetados de ambos os sexos antes do tratamento. Os animais estavam em diferentes faixas etárias. Todas as amostras foram transferidas para o laboratório por meio de transferência e cultivadas em Ágar Sabouraud e Dextrose (SDA) com e sem 0,05 g/mL e 0,4 g/mL de cloranfenicol e cicloheximida, respectivamente. Posteriormente, os ágares foram incubados a $25^{\circ} \mathrm{C} \mathrm{e} 37^{\circ} \mathrm{C}$. A porcentagem total de infecção ocular foi de 6,75\%, representando 49,2\% de infecção micótica. As manifestações clínicas predominantes nos búfalos infectados foram inflamação ocular com congestão, lacrimejamento, opacidade da córnea e edema. Os animais acometidos também apresentaram redução de produtividade. Diferentes isolados de fungos foram identificados a partir das amostras, incluindo Aspergillus fumigatus, Aspergillus flavus, Aspergillus niger, Penicillium spp., Alternaria spp., Fusarium spp., Candida spp., Cladosporium spp., Rhodotorula spp., Mucour spp. e Rizopus spp. Búfalos com menos de um ano de idade foram mais propensos a infecções micóticas do que com um ano ou mais. Além disso, os búfalos machos foram mais suscetíveis a infecção do que as fêmeas. Em conclusão, este estudo registrou o isolamento de vários tipos de fungos em olhos inflamados de búfalos. Além disso, a infecção ocular por fungos e os fatores de risco potenciais 
para ceratite fúngica em búfalos também foram observados. O estudo também aprovou o diagnóstico rápido de fungos por detecção microscópica direta e cultura. $\mathrm{O}$ autor recomenda outro estudo futuro, incluindo um grande número de rebanhos de búfalos no Iraque para determinar a epidemiologia desta condição no país.

Palavras-chave: Bubalino. Infecções oculares fúngicas. Aspergillus flavus. Mucour spp.

Correspondence to:

Karima Akool Al Salihi

Al Muthanna University, College of Veterinary Medicine,

Department of Preventive and Internal Medicine

66001, General street, Samawa, Iraq

e-mail: kama-akool18@mu.edu.iq

Received: December 20, 2020

Approved: May 24, 2021

How to cite: Khalaf JM, Karim AJ, Al Salihi KA. Buffaloes (Bubalus bubalis) mycotic eye infection: reported herd cases in Thi-Qar province, Iraq. Braz J Vet Res Anim Sci. 2021;58:e180221. https://doi.org/10.11606/issn.1678-4456. bjvras.2021.180221

\section{Introduction}

Buffaloes, among farm livestock, play an essential economical role, worldwide, mainly acting as dairy, meat, and draft animal activities (Borghese \& Moioli, 2011). Buffaloes mainly feed on straw and crop residues in crowded husbandry. This creates vision problems and might affect their activity and productivity or cause trauma or severe infestation with stable flies (Kalyankar et al., 2008). Eye diseases mostly affect vision and, in turn, the length of grazing, growth, and weight gain in both growing and adult animals (Handool, 2013). Many factors, such as environment, age, geography, habitat, season, and husbandry have been reported to influence the composition of conjunctival flora or low immunity (Ge et al., 2019; Johns et al., 2011). Studies regarding isolation and identification of conjunctival microorganism referred most frequently to saprophytic fungi in rabbits and horses, as well as humans (Bandyopadhyay et al., 2012; Bourguet et al., 2019; Ge et al., 2019; Khosravi et al., 2014; Kumar et al., 2019; Ledbetter, 2017; Shivaji et al., 2019). Fungi are widely prevalent microflora that occurs in soil, water, and air. More likely, they occur in the animal's skin, residing cornea, conjunctiva, and all animal environment (Pal, 2017). Some of these fungi are pathogenic and others become pathogenic following corneal injury (Maxwell et al., 2015). The ocular microbial flora consists of resident and transient bacteria, fungi, and Chlamydia (Andrew et al., 2003; Pinard et al., 2002). Such organisms exist in a balance between themselves and the immune system of the host. The resident microbial flora aids in maintaining a healthy ocular surface by preventing overgrowth of the potentially pathogenic agent. However, this normal flora becomes opportunistic and causes infection (Gilger, 2008). Keratomycosis is a common infection of the cornea caused by more than 30 fungal genera proceeding from conjunctival microflora or the surrounding atmosphere, introduced into corneal stroma after trauma or pre-existent microbial infection.

Secondary keratomycosis and stromal abscess are frequently reported in small and large ruminants as well as in horses (Klotz et al., 2000; Ledbetter, 2017). Keratomycosis occurs with a history of trauma due to plant material, geographic location, chronic use of topical antibiotics or corticosteroids, or an extremely prolonged course of disease despite appropriate treatment (Andrew et al., 2003). The identification of the etiology and the predisposing factors of corneal ulcers are important for the prevention and early treatment of the disease. Despite its significant contribution as a valuable economic animal in Iraq, the buffalo has received little attention and a paucity of scientific research regardless of considerable research carried out on cattle. A review of the literature revealed scarce information regarding mycotic eye infection in buffaloes (Bubalus bubalis) in Iraq as well as in Thi-Qar province. Consequently, this study intended to investigate the occurrence of mycotic infection related to total eye infection in the eyes of buffaloes.

\section{Materials and Methods}

\section{Animals}

A local herd of buffaloes comprised of 3,700 animals in Thi-Qar province had a history of eye infection. About 250 buffaloes were diagnosed with eye infections from early December 2017 to the end of November 2018. All infected animals were treated locally with antibiotic and anti-inflammatory ointment. Also, long-acting oxytetracyclines were injected intramuscularly for each animal.

\section{Samples collection}

Before treatment of the affected buffaloes, a sterile cotton swab was used to collect a deep corneal sample from both left and right eyes of 250 affected buffaloes. Samples were directly inoculated into the nutrient broth 
and transferred in a cool box to the Lab of Zoonotic Unit, College of Veterinary Medicine, the University of Baghdad within $6 \mathrm{~h}$ for further analysis. This study was approved by the animal ethical committee (Animal Care and Use Committee/ACUC approval no. 1791/28, Nov 2017).

\section{Isolation of fungi}

Swabs were directly inoculated on blood, MacConkey, and brain heart infusion, as well as on Sabourand dextrose (SDA) agar with and without $0.05 \mathrm{~g} / \mathrm{mL}$ and $0.4 \mathrm{~g} / \mathrm{mL}$ chloramphenicol and cycloheximide, respectively, and incubated at $25^{\circ} \mathrm{C}$ and $37^{\circ} \mathrm{C}$. Further incubation at $28 \pm 2{ }^{\circ} \mathrm{C}$ for 5-14 days with continuous follow-up of the fungal growth. Later, the culture was examined according to fungal standard criteria, including macroscopic examination of the colony morphology and reverse plate appearance. The yeast isolates were identified by direct microscopic examination stained with lactophenol cotton blue dye (Fluka-Switzerland'), and by using biochemical kit API AUX20C (BioMérieux," Germany). Further microscopic smears were prepared, fixed, and stained with conventional Gram stain.

\section{Statistical analysis}

Microsoft Office Excel and SPSS 17.0 (SPSS Inc, Chicago, IL, USA) programs were used in the current investigation to collect the obtained data and for statistical analysis. Chi-square $\left(x^{2}\right)$ and $t$-test were applied to detect the significant differences. Differences were considered significant at a level of $\mathrm{P}<0.05$.

\section{Results}

The number of buffaloes with eye infections was $250(6.75 \%)$ out of 3,700 animals. Of the 250 buffaloes, 123 (49.2\%) were reported with pure mycotic infection. Examination of infected eyes revealed a wide range of symptoms varying from lacrimation, mucous or mucopurulent discharge, photophobia, congestion of blood vessels and conjunctiva, the opacity of cornea to ulceration. The percentage of mycotic infection in buffalo eyes was $49 \%$ and categorized into $39 \%$ of molds identified as Aspergillus spp. (23\%), Penicillium spp. (6\%), Fusarium spp. (4\%), Cladosporium spp. (2\%), Mucor spp. (2\%) and Rhizopus spp. (2\%). The percentage of yeasts was (10\%) including Candida albicans (8\%) and Rhodotorula mucilagenosa (2\%) as shown in Table 1.

Calve buffaloes below one year of age were more prone to mycotic infection than buffalo calves older than one year old. Males were statistically higher than females (Table 2).

The results also showed a high percentage of fungus isolation in winter (72.35\%) followed by autumn (20.32\%), spring (5.69\%), and the lowest (1.62\%) in summer (Table 3). The right-sided eye was more prone than the left-sided eye as well as for mycotic infections (Table 4).

Table 1 - Type of molds isolated from eyes of buffaloes from a herd in Thi-Qar province, Iraq. Samples were collected from December 2017 to November 2018

\begin{tabular}{lccc}
\hline $\begin{array}{c}\text { Total isolates } \\
\text { (no=250) }\end{array}$ & Species & No & $\begin{array}{c}\text { Percentage } \\
\mathbf{( \% )}\end{array}$ \\
\hline Fungi & Aspergillus fumigatus & $\mathbf{2 8}$ & $\mathbf{1 1}^{\mathbf{d}}$ \\
(no=98; 39.2\%) & Aspergillus niger & $\mathbf{1 5}$ & $\mathbf{6}^{\mathbf{b c}}$ \\
& Aspergillus flavus & $\mathbf{1 5}$ & $\mathbf{6}^{\mathbf{b c}}$ \\
& Penicillium spp & $\mathbf{1 5}$ & $\mathbf{6}^{\mathbf{b c}}$ \\
& Fusarium spp & $\mathbf{1 0}$ & $\mathbf{4}^{\text {ab }}$ \\
& Cladosporium spp & $\mathbf{5}$ & $\mathbf{2}^{\mathbf{a}}$ \\
& Mucor spp & $\mathbf{5}$ & $\mathbf{2}^{\mathbf{a}}$ \\
& Rhizopus spp & $\mathbf{5}$ & $\mathbf{2}^{\mathbf{a}}$ \\
Yeasts & Candida albicans & $\mathbf{2 0}$ & $\mathbf{8}^{\mathbf{c}}$ \\
(no=25; 10\%) & Rhodotorula & $\mathbf{5}$ & $\mathbf{2}^{\mathbf{a}}$ \\
& mucilagenosa & & \\
& & $\mathbf{1 2 3}$ & $\mathbf{4 9}$ \\
\hline
\end{tabular}

Different small letters represent a significant difference between $\operatorname{sex}(\mathrm{p}<0.05)$

Table 2 - Mold infection from eyes of buffaloes from a herd in Thi-Qar province, Iraq according to age and sex. Samples were collected from December 2017 to November 2018

\begin{tabular}{cccc}
\hline \multirow{2}{*}{ Gender } & \multirow{2}{*}{ no $=$} & \multicolumn{2}{c}{ Age (years) } \\
\cline { 3 - 4 } & & $\mathbf{1}$ & $\mathbf{1}$ \\
\hline Female & 57 & $33(57.89 \%) \mathrm{Aa}$ & $15(26.31 \%) \mathrm{Ba}$ \\
Male & 193 & $74(38.34 \%) \mathrm{Ab}$ & $22(11.39 \%) \mathrm{Bb}$ \\
Total & 250 & $107(42.80 \%) \mathrm{A}$ & $37(14.80 \%) \mathrm{B}$ \\
\hline
\end{tabular}

Different small letters represent a significant difference between $\operatorname{sex}(\mathrm{p}<0.05)$; Different capital letters represent a significant difference between ages $(p<0.05)$

Table 3 - Mold infection from eyes of buffaloes from a herd in Thi-Qar province, Iraq according to seasons. Samples were collected from December 2017 to November 2018

\begin{tabular}{ccccc}
\hline \multirow{2}{*}{ Season } & \multicolumn{2}{c}{ Eye infection } & \multicolumn{2}{c}{ Mycotic infection } \\
\cline { 2 - 5 } & no= & \% & no= & $\%$ \\
\hline Spring & 23 & $9.2 \mathrm{Da}$ & 7 & $5.69 \mathrm{Ca}$ \\
Summer & 7 & $2.8 \mathrm{Ca}$ & 2 & $1.62 \mathrm{Da}$ \\
Autumn & 68 & $27.2 \mathrm{Ba}$ & 25 & $20.32 \mathrm{Ba}$ \\
Winter & 152 & $60.8 \mathrm{Aa}$ & 89 & $72.35 \mathrm{Aa}$ \\
Total & 250 & & 123 & \\
\hline
\end{tabular}

Different small letters represent a significant difference between columns $(p<0.05)$. Different capital letters represent a significant difference between rows $(\mathrm{p}<0.05)$

Table 4 - Mold infection from eyes of buffaloes from a herd in Thi-Qar province, Iraq according to the site of the eye affected. Samples were collected from December 2017 to November 2018

\begin{tabular}{ccc}
\hline & Eye infection & Mycotic infection \\
\hline Right & $219(87.6 \%) \mathrm{A}$ & $118(95.9 \%) \mathrm{A}$ \\
Left & $9(3.6 \%) \mathrm{C}$ & $5(4.1 \%) \mathrm{B}$ \\
Both & $22(8.8 \%) \mathrm{B}$ & 0 \\
Total & 250 & 123 \\
\hline
\end{tabular}

Different letters represent a significant difference between rows $(\mathrm{p}<0.05)$ 


\section{Discussion}

The susceptibility of various animals to keratomycosis is still questionable worldwide due to the variable ecosystem in both health and disease (Acharya et al., 2017; Bond et al., 2020). Among animals, buffaloes are the most susceptible due to many factors such as the environment where they live with a high concentration of fungi in the humid and hot environment, as well as the accidental vegetal ocular harm (Lamagna et al., 2015). The results of this study are compatible with previous results in Italy, which had studied the cytology feature and the microbiology of ocular conjunctiva in healthy Mediterranean buffaloes (Lamagna et al., 2015). The results of the current study also agree with previous results on fungal keratoconjunctivitis in Indian buffaloes (Rajesh et al., 2009).

Keratomycosis is more prevalent in the eyes of buffaloes due to corneal erosion caused by hay on lateral recumbency, so the microorganism can adhere to the cornea and cause infection. The findings of this study showed that the incidence of the disease was significantly highest in the right-sided eye and might be affected by the way that buffaloes lie down on the ground. Incidental ocular trauma by plant leaves or vegetative materials is also a facilitating factor in animals, which can lead to fungal keratomycosis and corneal ulcer after the release of mycotoxin and proteolytic enzymes, producing corneal destruction. There are variations in the fungi according to the geographic area and season, additionally Aspergillus, Penicillium, Cladosporium spp. are predominant in most studies on conjunctival and cornea microbiota of animal (Doczi et al., 2004).

Fungi are incriminated in 30 to $62 \%$ of the total microbial corneal ulcers, causing blindness in tropical developing countries (Bandyopadhyay et al., 2012). These reported observations are consistent with the current fungi prevalence recorded at $49.2 \%$. No specific clinical signs including blepharospasm, epiphora, miosis, corneal opacity, and vascularization were observed in fungal keratitis (Ge et al., 2019). Globally, saprophytic fungi can cause mycotic keratitis in humans and animals, mainly horses (Behdad \& Araghi-Sooreh, 2014; Khosravi et al., 2014; Kumar et al., 2019; Maxwell et al., 2015), cows (Handool 2013; Voelter-Ratson et al., 2013), donkeys (Nardoni et al., 2007), dogs and cats (Samuelson et al., 2010). Scarce data are available on buffaloes. The findings of this study also referred to many organisms reported by previous studies, although differences in prevalence or some microorganisms like Curvularia spp., Drechsclera spp., and Acremonium species have not been recorded (Sundaram et al., 1989).

The results of the current study revealed the exceeding of fungal isolation of the yeasts and among different fungi genera. Also, the saprophytic fungi, such as Aspergillus spp., Penicillium spp., and Fusarium spp. were the most prevalent genera. The high incidence of fungi in the soil, decaying vegetation, seeds, and grains or air can occasionally lead to ocular as well as superficial infections (Seyedmousavi et al., 2018). Aspergillus causes many pathological effects in veterinary medicine, as well as in man. The findings of this investigation agreed with many other studies (Acharya et al., 2017; Ge et al., 2019; Handool, 2013; Samuelson et al., 2010), which recorded the predominance of species of Aspergillus and Penicillium and Cladosporium with a different prevalence. Samuelson et al. (2010) isolated fungi from infected and healthy cows' eyes in Florida. According to different management of cows, Sgorbini et al. (2010) found that the total eyes of healthy cows were positive for fungal contamination ranging from 55 to $100 \%$, and it can present in conjunctiva sac as transit seed from the environment. A diverse result was reported in India that showed the isolation of Aspergillus flavus and Aspergillus fumigatus from a four-month-old buffalo calf suffering from an ophthalmic traumatic injury while grazing on pasture. The Aspergillus spp. was predominant in healthy horses at $55-62 \%$. It can be isolated in conjunction with Fusarium spp. causing equine ulcerative keratomycosis or with Curvularia spp. causing necrotic conjunctivitis resulting in trauma and blindness in a gopher tortoise (Ledbetter, 2017; Pinard et al., 2002). The results of this study are compatible with previous studies done elsewhere in the world that recorded zygomycetes such as Rhizopus spp. in keratitis after trauma and concerning animal species, geography, and climate. The results agree with Khosravi et al. (2014), who isolated Rhizopus at 15.9\%, Penicillium spp. At 15.1\% and Aspergillus spp. At 19.9\%.

Intraocular infection caused by a major nosocomial pathogen, Candida species, can have devastating visual consequences. Candidemia may lead to chorioretinitis. Candida spp. is incriminated in causing conjunctivitis after tropical corticosteroid and antibacterial therapy of an inflamed eye (Nardoni et al., 2007). It was isolated from healthy buffaloes' eyes, in addition to Alternaria spp. and Malassezia spp. It was also reported after gastrointestinal surgery.

The Fusarium spp. are saprophytes that live in the soil and are found by researchers as the most frequent cause of keratomycosis during summer (Voelter-Ratson et al., 2013). It was also the most common isolate from corneal ulcer after Aspergillus spp. (Ge et al., 2019). However, another researcher reported Fusarium solani as the cause of oculomycosis in water buffaloes and keratitis in equines $(\mathrm{Pal}, 2017)$ with an incidence reported in up to $65 \%$ of cases. The fungal infection was also reported in more stromal destruction cases than 
Aspergillus spp. The Aspergillus species and Candida albicans are also common causes, while Curvularia and Acremonium species occur less often. However, Sundaram et al. (1989) isolated Aspergillus spp. as the most common isolated fungi followed by Penicillium and Fusarium species to a lesser degree from 150 cases of corneal ulcers in India.

The results of this study showed that the male buffaloes were three times more affected than females and almost similar morbidity in ages younger than one year. This might be explained because male animals are usually more rambunctious than females. Controversially, Handool (2013) recorded a higher incidence in females than males. That younger animals are more prone to eye infection might be attributed to accidental injuries and trauma while suckling milk. According to seasons, the results of this study also showed a high percentage of fungus isolated in winter $(72.35 \%)$, followed by autumn (20.32\%), spring (5.69\%), and the lowest (1.62\%) in summer. The highly affected animals were mostly in cold weather in autumn and winter, where closed management is practiced. These results are in agreement with the similar finding reported by Handool (2013). An explanation of the high incidence of fungal isolates in the cold months may be attributed to the overcrowding and increased direct contact of animals in their stockyards and fed on rough vegetative food being the commonest risk factor for trauma and injury among

\section{References}

Acharya Y, Acharya B, Karki P. Fungal keratitis: study of increasing trend and common determinants. Nepal J Epidemiol. 2017;7(2):685-93. http://dx.doi.org/10.3126/nje. v7i2.17975. PMid:29181230.

Andrew SE, Nguyen A, Jones GL, Brooks DE. Seasonal effect on the aerobic bacterial and fungal conjunctival flora of normal thorough breed brood mares in Florida. Vet Ophthalmol. 2003;6(1):45-50. http://dx.doi.org/10.1046/ j.1463-5224.2003.00265.x. PMid:12641842.

Bandyopadhyay S, Das D, Mondal KK, Ghanta AK, Purkrit SK, Bhasrar R. Epidemiology and laboratory diagnosis of fungal corneal ulcer in the Sundarban Region of West Bengal, eastern India. Nepal J Ophthalmol. 2012;4(1):2936. http://dx.doi.org/10.3126/nepjoph.v4i1.5847.

Behdad A, Araghi-Sooreh A. Investigation of fungal isolated of normal conjunctival sac in the Turkmen (Yamud) Horses. J Vet Micro. 2014;10(1):65-43. them. However, Bandyopadhyay et al. (2012) argued that the prevalence of fungal conjunctival infections was lower in animals housed strictly outdoors, and this hypothesis is supported by the results of the current study.

In conclusion, the results of this study suggest the potential risk factors for fungal keratitis in buffaloes. The results of this study also show that the rapid diagnosis made by direct microscopic detection of fungi and by culture can be used for detection of the infection. Buffalo calves below one-year-old were more prone to mycotic infection than one-year-old calves. Male buffaloes were more susceptible to infection than females. The author recommends future studies on buffaloes' eye infections to determine the epidemiology of the disease and its causes in Iraq.

\section{Conflict of Interest}

The authors declare no conflict of interest.

\section{Ethics Statement}

This study was approved by the animal ethical research committee / Al Muthanna University, College of Veterinary Medicine.

\section{Acknowledgements}

The authors appreciated Dr Nawal Dh Mahmoud for her technical support.

Bond R, Morris DO, Guillot J, Bensignor EJ, Robson D, Mason KV, Kano D, Hill PB. Biology, diagnosis and treatment of Malassezia dermatitis in dogs and cats Clinical Consensus Guidelines of the World Association for Veterinary Dermatology. Vet Dermatol. 2020;31(1):27-e4.

Borghese A, Moioli B. Buffalo: mediteranean region. Encyclopedia of Dairy Sciences. 2011;1:780-4.

Bourguet A, Desprez I, Volait L, Guyonnet A, Pignon C, Boulouis HJ, Guillot J, Chahory S. Conjunctival bacterial and fungal flora and cutaneous fungal flora in healthy domestic rabbits (Oryctolagus cuniculus). J Small Anim Pract. 2019;60(7):417-22. http://dx.doi.org/10.1111/jsap.12989. PMid:30875093.

Dóczi I, Gyetvai T, Kredics L, Nagy E. Involvement of Fusarium spp. In fungal keratitis. Clin Microbiol Infect. 2004;10(9):773-6. http://dx.doi.org/10.1111/j.14690691.2004.00909.x. PMid:15355406. 
Ge C, Wei C, Yang BX, Cheng J, Huang YS. Conjunctival microbiome changes associated with fungal keratitis: metagenomic analysis. Int J Ophthalmol. 2019;12(2):194200. PMid:30809472.

Gilger BC. Immunology of ocular surface. Vet Clin North Am Small Anim Pract. 2008;38(2):223-31, v. http://dx.doi. org/10.1016/j.cvsm.2007.11.004. PMid:18299004.

Handool HH. Isolation and identification of some genera and species of bacteria and fungi from conjunctiva in cattle in AL-Diwaniya. AL -Qadisiya journal of Vet. Med Sci. 2013;12(2):55-62.

Johns IC, Baxter K, Booler H, Hicks C, Menzies-Gow N. Conjunctival bacterial and fungal flora in healthy horses in the UK. Vet Ophthalmol. 2011;14(3):195-9. http://dx.doi. org/10.1111/j.1463-5224.2010.00867.x. PMid:21521444.

Kalyankar SD, Chavan AA, Khedkar CD, Kalyankar SP. Studies On Management Practices of Buffaloes In Different Agro-Climatic Zones Of Maharashtra. Indian J Anim Res. 2008;42(3):157-63.

Khosravi AR, Nikaein D, Sharifzadeh A, Gharagozlou F. Ocular fungi flora from healthy horses in Iran. J Mycol Med. 2014;24(1):29-33. http://dx.doi.org/10.1016/j. mycmed.2013.10.006. PMid:24411178.

Klotz SA, Penn CC, Negvesky GJ, Butrus SI. Fungal and parasitic infections of the eye. Clin Microbiol Rev. 2000;13(4):662-85. http://dx.doi.org/10.1128/CMR.13.4.662. PMid:11023963.

Kumar A, Khurana A, Sharma M, Chauhan L. Causative fungi and treatment outcome of dematiaceous fungal keratitis in North India. Indian J Ophthalmol. 2019;67(7):1048-53. http://dx.doi.org/10.4103/ijo.IJO_1612_18. PMid:31238406.

Lamagna B, Pasolini MP, Nizza S, Mallardo K, Formicola M, Costagliola A, Fatone G, Fiorito F, Paciello O, De Martino L. Conjunctival cytological examination, bacteriological culture, and antimicrobial resistance profiles of healthy Mediterranean buffaloes (Bubalus bubalis) from Southern Italy. Asian Pac J Trop Biomed. 2015;5(11):889-95. http:// dx.doi.org/10.1016/j.apjtb.2015.06.017.

Ledbetter EC. Antifungal therapy in equine ocular mycotic infections. Vet Clin North Am Equine Pract. 2017;33(3):583-605. http://dx.doi.org/10.1016/j.cveq.2017.08.001. PMid:28958862.

Maxwell KM, Plummer CE, Brooks DE. The fungal plaque form of equine keratomycosis. Vet Med Anim Sci. 2015;3:110. http://dx.doi.org/10.7243/2054-3425-3-2.
Nardoni S, Sgorbini M, Barsotti G, Corazza M, Mancianti F. (Counjunctival fungal flora in healthy donkey. Vet Ophthalmol. 2007;10(4):207-10. http://dx.doi.org/10.1111/ j.1463-5224.2007.00537.x. PMid:17565551.

Pal M. First report of isolation Fusarium solani from equine keratitis in Gujarat, India. EC Microbiology. 2017;9(5):174-6.

Pinard CL, Brightman AH, Yeary TJ, Everson TD, Cox LK, Chengappa MM, Davidson HJ. Normal conjunctival flora in north America opossum (didelphis virginiana) and raccoon (procyon lotor). J Wildl Dis. 2002;38(4):851-5. http:// dx.doi.org/10.7589/0090-3558-38.4.851. PMid:12528457.

Rajesh K, Suresh K, Syaamasunder N. Infectious bovine keratoconjunctivitis in abuffalo and therapeutic aspects. Buffalo Bull. 2009;28(3):110-2.

Samuelson DA, Andresen TL, Gwin RM. Conjunctival fungal flora in horses, cattle, dogs, and cats. Vet Ophthalmol. 2010;13(4):227-34.

Seyedmousavi S, Bosco SMG, de Hoog S, Ebel F, Elad D, Gomes RR, Jacobsen ID, Jensen HE, Martel A, Mignon B, Pasmans F, Piecková E, Rodrigues AM, Singh K, Vicente VA, Wibbelt G, Wiederhold NP, Guillot J. Fungal infections in animals: a patchwork of different situations. Med Mycol. 2018;1(56, suppl_1):165-87.http://dx.doi.org/10.1093/mmy/ myx104. PMid:29538732.

Sgorbini M, Barsotti G, Nardoni S, Brombin M, Sbrana A, Mancianti F, Corazza M. Seasonal prevalence of fungi in the conjunctival fornix of healthy cows during a 2-year study. Vet Ophthalmol. 2010;13(4):227-34. http://dx.doi. org/10.1111/j.1463-5224.2010.00788.x.

Shivaji S, Jayasudha R, Sai Prashanthi G, Kalyana Chakravarthy S, Sharma S. The human ocular surface fungal microbiome. Invest Ophthalmol Vis Sci. 2019;60(1):451-9. PMid:30703210.

Sundaram BM, Badrinath S, Subramanian S. Studies on mycotic keratitis. Mycosis. 1989;32(11):568-72. http://dx.doi. org/10.1111/j.1439-0507.1989.tb02183.x. PMid:2615780.

Voelter-Ratson K, Monod M, Braun U, Spiess BM. Ulcerative fungal keratitis in brown swiss cow. Vet Ophthalmol. 2013;16(6):464-6. http://dx.doi.org/10.1111/vop.12037. PMid:23437914.

Financial Support: This work was supported by College of Veterinary Medicine, University of Baghdad. 